\title{
Additions to the New Brunswick Museum Palaeontology Type Collection (1988-1996)
}

\author{
Randall F. Miller \\ Steinhammer Palaeontology Laboratory, New Brunswick Museum, \\ 277 Douglas Avenue, Saint John, New Brunswick E2K 1E5, Canada \\ Date Received December 4, 1996 \\ Date Accepted December 19, 1996
}

\begin{abstract}
Since publication of the New Brunswick Museum's first catalogue of type fossils in 1988, over 240 specimen records have been added to the collection of primary and secondary types. The list includes fossils recovered from the collection of G.F. Matthew that are considered to have type, or probable type, status. New specimens resulting from publications since 1988 include invertebrates, ichnofossils and vertebrates.
\end{abstract}

\begin{abstract}
Depuis la publication du premier catalogue de fossiles stratigraphiques du Musée du Nouveau-Brunswick en 1988, on a ajouté plus de 240 enregistrements de spécimens à la collection de types primaires et secondaires. La liste englobe des fossiles provenant de la collection de G.F. Matthews, considérés comme des fossiles de types définis ou de types et valeurs probables. Les nouveaux spécimens découlant des communications publiées depuis 1988 comprennent des invertébrés, des ichnofossiles et des vertébrés.
\end{abstract}

[Traduit par la rédaction]

\section{INTRODUCTION}

When the New Brunswick Museum (NBM) published its Catalogue of Type Fossils (Miller, 1988a), it was the institution's first compilation of primary and secondary type specimen records. This historically important collection dates back to the mid-1800s and includes specimens from Gesner's 1837 to 1842 geological survey of the province. Many of the specimens belonged to the Natural History Society of New Brunswick (Miller and Buhay, 1988). Research on collection development has assisted in documenting older material, and aspects of the collection's history have recently been published (Landing and Miller, 1988; Miller and Buhay, 1988; Miller, 1988b, 1994). Since 1988, over 240 specimens have been added to the type collection. This includes material studied in the nineteenth to early twentieth century by G.F. Matthew as well as new specimens added in recent years, primarily by R.K. Pickerill and colleagues (ichnofossils and invertebrates), H.J. Hofmann and I.M. Patel (ichnofossils), E. Landing (small shelly fossils) and R.F. Miller (invertebrates and vertebrates). This list and the previous type catalogue (Miller, 1988a) include Cited and Referred Specimens found in older literature that may be of interest to researchers seeking specimens. Notes on the revision of type specimens (Fillion and Pickerill, 1990; Miller, 1990a, 1995a, 1995b, 1996a) and the transfer of types to the NBM collection (Miller, 1989; Pickerill, 1990) have appeared since 1988.

\section{NBM PALAEONTOLOGY COLLECTION}

This list contains additions to the type collection since 1987-88, and includes references published, or in press, at the end of 1996. Records are presented in the same order used in the museum's first catalogue, and are maintained on a computer database using INMAGIC $®$ software. Information concerning type or other fossils can be obtained by writing the Curator of Geology, New Brunswick Museum, 277 Douglas Avenue, Saint John, New Brunswick E2K 1E5, Canada. The type status of older specimens marked with "?" indicates uncertainty. It is often difficult to determine if fossils in the Matthew collection are actually figured in his publications. However, so much of the older material has been inaccessible for so long, it is important to make researchers aware specimens do in fact exist. A summary of the type holdings of the NBM is presented below.

Total Specimen (Lots) in NBM Palaeontology Collection: 8,217

Type Holdings: Holotypes 56, Syntypes 148, Paratypes 35, Paralectotypes 14, Figured/Cited/Referred 573; Miscellaneous/ Unconfirmed 65

Phyla Represented by Holotypes: 8 (incl. Ichnotaxa, Problematica)

Time Coverage: Late Precambrian to Quaternary

Publications Referring to Collection - Total: 193

\section{Brachiopoda}

Strophomena atava Matthew: Syntype NBMG 4553; 4554; 4555

Matthew, 1893. Trans. Roy. Soc. Can. 10, sec. IV, p. 102.

Silver Falls Fm., Cambrian/Ordovician, Navy Island, Saint John, New Brunswick.

Remarks: One specimen labelled type, uncertain if figured. See: ROM catalogue, p.46, Eoorthis atava (Matthew). 


\section{Mollusca}

Aldanella attleborensis (Shaler and Foerste): Fig. Spec. NBMG 10031

Landing, 1996. Can. J. Earth Sci. 33, p. 1189, fig. 5b,c.

Fosters Point Fm.?, Cambrian, Cradle Brook, New Brunswick.

"Allatheca" degeeri (Holm): Fig. Spec. NBMG 10036; 10037

Landing, 1996. Can. J. Earth Sci. 33, p. 1189, fig. 5h,i.

Fosters Point Fm.?, Cambrian, Cradle Brook, New Brunswick.

Buccinum undatum Linnaeus: Ref. Spec. NBMG 8544

Thomas et al., 1973. Can. J. Earth Sci. 10, p. 1330.

Quaternary, Shippegan, New Brunswick.

Chlamys islandicus (Müller): Ref. Spec. NBMG 8539

Thomas et al., 1973. Can. J. Earth Sci. 10, p. 1330.

Quaternary, Shippegan, New Brunswick.

Coleoloides typicalis Walcott: Fig. Spec. NBMG 10038

Landing, 1996. Can. J. Earth Sci. 33, p. 1189, fig. 5j.

Fosters Point Fm.?, Cambrian, Cradle Brook, New Brunswick.

Hiatella arctica (Linné): Ref. Spec. NBMG 8538

Thomas et al., 1973. Can. J. Earth Sci. 10, p. 1330.

Quaternary, Shippegan, New Brunswick.

Mactra Linné: Ref. Spec.? NBMG 4230

Chalmers, 1890. Annual Report Part N, IV, Geol. Surv. of

Can., p. $64 \mathrm{~N}$.

Quaternary, Quaco, New Brunswick.

Remarks: One specimen, possibly referred to by Chalmers (1890).

Mya calcarea (Gmelin): Ref. Spec. NBMG 8541

Thomas et al., 1973. Can. J. Earth Sci. 10, p. 1330.

Quaternary, Shippegan, New Brunswick.

Mya truncata Linné: Ref. Spec. NBMG 8540

Thomas et al., 1973. Can. J. Earth Sci. 10, p. 1330.

Quaternary, Shippegan, New Brunswick.

Natica clausa Broderip and Sowerby: Ref. Spec. NBMG 8543

Thomas et al., 1973. Can. J. Earth Sci. 10, p. 1330.

Quaternary, Shippegan, New Brunswick.

Serripes groenlandicus (Bruguière): Ref. Spec. NBMG 8542

Thomas et al., 1973. Can. J. Earth Sci. 10, p. 1330.

Quaternary, Shippegan, New Brunswick.

Solen Linné: Ref. Spec.? NBMG 4272

Chalmers, 1890. Annual Report Part N, IV, Geol. Surv. of Can., p. $64 \mathrm{~N}$.

Quaternary, Quaco, New Brunswick.

Remarks: two specimens, possibly referred to by Chalmers (1890).

\section{Arthropoda}

Balanus crenatus Bruguière: Ref. Spec. NBMG 10088

Thomas et al., 1973. Can. J. Earth Sci. 10, p. 1330.

Quaternary, Shippegan, New Brunswick.

Balanus hameri Ascon: Ref. Spec. NBMG 8545

Thomas et al., 1973. Can. J. Earth Sci. 10, p. 1330.

Quaternary, Shippegan, New Brunswick.

Coleoptera: Ref. Spec. NBMG 3868-3905

Miller et al., 1987. Can. J. Earth Sci. 24, p. 2099.

Quaternary, Evertt, Ontario.

Remarks: Multiple specimens per slide, additional material in vials.

Leaia silurica Matthew: Holotype NBMG 4573/1,2

Matthew, 1910. Trans. Roy. Soc. Can., 3 (4), p. 115, pl. IV, fig. 3.

Cumberland Gp., Lancaster Fm., Pennsylvanian, Saint John, New Brunswick.

Remarks: Status reviewed by Miller (1995a).

Pterygotus anglicus Agassiz: Fig. Spec. NBMG 9774/1,2; 9775

Miller, 1996b. Atlan. Geol. 32, p. 96, figs. 3a-c.

Campbellton Fm., Devonian, Atholville, New Brunswick.

\section{Annelida}

Byronia annulata Matthew: Holotype? NBMG 3154

Matthew, 1899a. Trans. Roy. Soc. Can. 5 (4), p. 42, pl. 1, fig. 2 .

Stephen Fm., Cambrian, Mount Stephen, British Columbia.

Remarks: Although the original figure caption suggests a complete tube was examined, this may be Matthew's holotype. Holotype not at ROM.

Chancelloria sp.: Fig. Spec. NBMG 10039; 10040

Landing, 1996. Can. J. Earth Sci. 33, p. 1189, fig. 5k,1.

Fosters Point Fm.?, Cambrian, Cradle Brook, New Brunswick.

Trentonia shegiriana Pickerill and Forbes: Holotype NBMG 6501

Pickerill and Forbes, 1978. Can. J. Earth Sci. 15, p. 661, fig. 2,3.

Trenton Gp., Ordovician, near Quebec City, Quebec.

Remarks: Transfer of specimen to NBM cited in Pickerill (1990a).

Urotheca flagellum Matthew: Ref. Spec.? NBMG 3152

Matthew, 1899a. Trans. Roy. Soc. Can. 5 (4), p. 40.

Stephen Fm., Cambrian, Mount Stephen, British Columbia.

Remarks: This specimen found in same box as NBMG 3153, not specifically identified. Holotype at ROM. 
Urotheca parva Matthew: Ref. Spec.? NBMG 3153

Matthew, 1899a. Trans. Roy. Soc. Can. 5 (4), p. 41.

Stephen Fm., Cambrian, Mount Stephen, British Columbia.

Remarks: This specimen found in same box as NBMG 3152 , not specifically identified. Holotype at ROM.

\section{Echinodermata}

Ophiura sarsi Lütken: Fig. Spec. NBMG 4007/1-4; Cited Spec. NBMG 4561; 4575; 4578; 6014; 8349; 8350; 8440

Miller and McAlpine, 1991. Atlan. Geol. 27, p. 111, fig. 3a,b.

Quaternary, Saint John, New Brunswick.

Remarks: NBMG 4007 may be specimens of Ophioglypha sarsii referred to by Dawson $(1893$, p. 218) as occurring in Leda clay, near Saint John, New Brunswick.

Ophiura cf. O. sarsi Lütken: Cited Spec. NBMG 4560; 4577; 4622-4627; 6015; 8347; 8348

Miller and McAlpine, 1991. Atlan. Geol. 27, p. 113.

Quaternary, Saint John, New Brunswick.

Strongylocentrotus droebachiensis Müller: Fig. Spec. NBMG 4246; Cited Spec. NBMG 4640

Miller and McAlpine, 1991. Atlan. Geol. 27, p. 112, fig. 2a-e.

Quaternary, Saint John, New Brunswick.

Strongylocentrotus droebachiensis Müller: Cited Spec. NBMG 8537

Thomas et al., 1973. Can. J. Earth Sci. 10, p. 1330.

Quaternary, Shippegan, New Brunswick.

Monobathrid camerate gen. et sp. indet.: Fig. Spec. NBMG 9942-9944; Cited Spec. NBMG 9945

Donovan and Pickerill, 1995. Atlan. Geol. 31, p. 82, figs. 2-4.

Arisaig Gp., Moydart Fm., Arisaig, Nova Scotia.

\section{Other}

Camenella baltica (Bengston): Fig. Spec. NBMG 10033; 10034

Landing, 1996. Can. J. Earth Sci. 33, p. 1189, fig. 5e,f.

Fosters Point Fm.?, Cambrian, Cradle Brook, New Brunswick.

Halkieria sp.: Fig. Spec. NBMG 10041-10043

Landing, 1996. Can. J. Earth Sci. 33, p. 1189, fig. 5m-0.

Fosters Point Fm.?, Cambrian, Cradle Brook, New Brunswick.

Sunnaginia imbricata Missarzhevsky: Fig. Spec. NBMG 10032

Landing, 1996. Can. J. Earth Sci. 33, p. 1189, fig. 5d.

Fosters Point Fm.?, Cambrian, Cradle Brook, New Brunswick.

Volborthella tenuis Schmidt: Ref. Spec.? NBMG 8027/1,2

Matthew, 1890a. Trans. Roy. Soc. Can. 7 (4), p. 156, pl. 8, fig. 5a,b.
Yochelson (1981) U.S.G.S., Open File Report 81-743, p. 246.

Saint John Gp., Ratcliffe Brook or Hanford Brook Fm., Cambrian, Belyeas Landing, New Brunswick.

Remarks: uncertain if these are Matthew's figured specimens.

\section{Ichnotaxa/Trace Fossils}

Arenicolites ichnosp.: Cited Spec. NBMG 4404

Fillion and Pickerill, 1990. Palaeontographica Canadiana No. 7, p. 19.

Cambrian/Ordovician, Great Bell Island, Conception Bay, Newfoundland.

Remarks: may be part of suite noted by Matthew (1899b, pp. 71-72) as Arenicolites antiquatus.

Arthraria antiquata Billings: Cited Spec. NBMG 4557

Fillion and Pickerill, 1990. Palaeontographica Canadiana No. 7, p. 20.

Cambrian/Ordovician, Great Bell Island, Conception Bay, Newfoundland.

Remarks: may be part of suite noted by Matthew (1899b, pp. 71-72) as Arenicolites antiquatus.

Arthropodichnus chelopodus Greiner: Holotype NBMG 4615; Paratype NBMG 4616

Greiner, 1972. Can. J. Earth Sci. 9, p. 1776, figs. 11, 12, 13.

Jacquet River Fm., Devonian, Jacquet River, Kettlehole, New Brunswick.

Remarks: transfer of specimens to NBM cited in Miller (1989).

Arthropodichnus jacquetensis Greiner: Holotype NBMG 4608; Paratype NBMG 4609-4614

Greiner, 1972. Can. J. Earth Sci. 9, p. 1774, fig. 1-8.

Jacquet River Fm., Devonian, Jacquet River, Kettlehole, New Brunswick.

Remarks: probably Protovirgularia dichotoma M'Coy, according to Han and Pickerill (1994b). Transfer of specimens to NBM cited in Miller (1989).

Bichordites monastiriensis Plaziat and Mahmoudi: Fig. Spec. NBMG 8612-8619

Pickerill et al., 1992. Ichnos 2, p. 2, fig. 3a-1.

Quaternary, St. Thomas, Jamaica.

Compaginatichnus forbesi Pickerill: Holotype NBMG 4595; Paratype NBMG 4596-4600

Pickerill, 1989. J. Paleont. 63, p. 914, figs. 2, 3, 4.

Matapedia Gp., Ordovician, confluence of Upsalquitch and Restigouche rivers, New Brunswick.

Cosmorhaphe cf. gracilis Książkiewicz: Fig. Spec. NBMG 8844

Pickerill et al., 1993a. Atlan. Geol. 29, p. 62, fig. 2a.

Richmond Fm., Tertiary, Port Maria, Jamaica. 
Cruziana semiplicata Salter: Cited Spec. NBMG 4402; 4403 Fillion and Pickerill, 1990. Palaeontographica Canadiana No. 7, p. 27.

Cambrian/Ordovician, Great Bell Island and Kelly's Island, Conception Bay, Newfoundland.

Cruziana ichnosp.: Fig. Spec. NBMG 9946

Pickerill, 1995. Atlan. Geol. 31, p. 104, fig. 2.

Lotbinière Fm., Ordovician, Montmorency Falls, Quebec.

Dactyloidites ottoi (Geinitz): Fig. Spec. NBMG 8603; 8604 Pickerill et al., 1993b. J. Paleont. 67, p. 1073, figs. 2.6, 3. Tertiary, Round Hill, Farquars Beach, Jamaica.

Diplichnites ichnosp. C: Cited Spec. NBMG 4402

Fillion and Pickerill, 1990. Palaeontographica Canadiana No. 7, p. 32.

Cambrian/Ordovician, Great Bell Island, Conception Bay, Newfoundland.

Helminthopsis abeli Książkiewicz: Fig. Spec. NBMG 9670-9676 Han and Pickerill, 1995. Ichnos 4, p. 103, figs. 7a-e, 8a,b. Tobique Gp., Wapske Fm., Devonian, New Brunswick.

Helminthopsis cf. granulata Książkiewicz: Fig. Spec. NBMG 9682

Han and Pickerill, 1995. Ichnos 4, p. 107, fig. $9 f$.

Tobique Gp., Wapske Fm., Devonian, New Brunswick.

Helminthopsis hieroglyphica Heer: Fig. Spec. NBMG 9676-9681 Han and Pickerill, 1995. Ichnos 4, p. 107, figs. 8b, 9a-e. Tobique Gp., Wapske Fm., Devonian, New Brunswick.

Helminthopsis ichnosp.: Fig. Spec. NBMG 9683

Han and Pickerill, 1995. Ichnos 4, p. 109, fig. 10.

Tobique Gp., Wapske Fm., Devonian, New Brunswick.

Helminthoidichnites tenuis Fitch: Hypotype NBMG 4008 Hofmann and Patel, 1989. Geol. Mag. 126, p. 141, fig. 2a. Saint John Gp., Ratcliffe Brook Fm., Cambrian, Hanford Brook, New Brunswick.

Lobichnus variabilis Kemper: Fig. Spec. NBMG 9938 Norman and Pickerill, 1996. Ichnos 4, p. 234, fig. 3. Devonian, Dockendorff Group, Chapman Sandstone, Presque Isle, Maine.

Lockeia avalonensis Fillion and Pickerill: Cited Spec. NBMG 4399

Fillion and Pickerill, 1990. Palaeontographica Canadiana No. 7, p. 39.

Cambrian/Ordovician, Great Bell Island, Conception Bay, Newfoundland.

Lockeia siliquaria James: Cited Spec. NBMG 4399

Fillion and Pickerill, 1990. Palaeontographica Canadiana No. 7, p. 39.

Cambrian/Ordovician, Great Bell Island, Conception Bay, Newfoundland.
Monocraterion ichnosp.: Fig. Spec. NBMG 4009

Hofmann and Patel, 1989. Geol. Mag. 126, p. 141, fig. 2c.

Saint John Gp., Ratcliffe Brook Fm., Cambrian, Hanford Brook, New Brunswick.

Monomorphichnus lineatus Crimes, Legg, Marcos and Arboleya: Cited Spec. NBMG 4402

Fillion and Pickerill, 1990. Palaeontographica Canadiana No. 7, p. 42.

Cambrian/Ordovician, Great Bell Island, Conception Bay, Newfoundland.

Neonereites multiserialis Pickerill and Harland: Fig. Spec. NBMG 8375-8377

Pickerill, 1991. Atlan. Geol. 27, p. 121, fig. 2.

Tobique Gp., Wapske Fm., Devonian, Little Tobique River, New Brunswick.

Palaeochorda setacea Matthew: Syntype? NBMG 8178 Matthew, 1890a. Trans. Roy. Soc. Can. 7 (4), p. 145.

Saint John Gp., Hanford Brook Fm., Cambrian, Hanford Brook, New Brunswick.

Paleodictyon ichnosp.: Fig. Spec. NBMG 6460

Pickerill, 1990b. Atlan. Geol. 26, p. 159, fig. 3.

Albert Fm., Mississippian, Norton, New Brunswick.

Paleodictyon ? ichnosp.: Fig. Spec. NBMG 8845

Pickerill et al., 1993a. Atlan. Geol. 29, p. 64, fig. 2c.

Richmond Fm., Tertiary, Port Maria, Jamaica.

Palaeophycus tubularis Hall: Fig. Spec. NBMG 4010/3,4,5 Hofmann and Patel, 1989. Geol. Mag. 126, p. 141, fig. 2d.

Saint John Gp., Ratcliffe Brook Fm., Cambrian, Hanford Brook, New Brunswick.

Palaeophycus tubularis Hall: Cited Spec. NBMG 4398; 4399; 4400; 4401

Fillion and Pickerill, 1990. Palaeontographica Canadiana No. 7, p. 45.

Cambrian/Ordovician, Great Bell Island, Conception Bay, Newfoundland.

Paleophycus ichnosp.: Cited Spec. NBMG 4556; 4557

Fillion and Pickerill, 1990. Palaeontographica Canadiana No. 7, p. 46.

Cambrian/Ordovician, Great Bell Island, Conception Bay, Newfoundland.

Remarks: may be part of suite noted by Matthew (1899b, pp. 71-72) as Arenicolites antiquatus.

"pascichnia": Fig. Spec. NBMG 4617; 4618

Greiner, 1972. Can. J. Earth Sci. 9, p. 1772, fig. 9, 10.

Jacquet River Fm., Devonian, Jacquet River, Kettlehole, New Brunswick.

Remarks: probably Helminthopsis abeli, according to Han and Pickerill (1995). Transfer of specimens to NBM cited in Miller (1989). 
Phycodes templus Han and Pickerill: Holotype NBMG 9202; Paratype NBMG 9203-9209

Han and Pickerill, 1994a. Atlan. Geol. 30, p. 39, figs. 2 to 4.

Tobique Gp., Wapske Fm., Devonian, Riley Brook, New Brunswick.

Phycodes templus Han and Pickerill: Fig. Spec. NBMG 9812 Pickerill et al., 1995. Atlan. Geol. 31, p. 3, fig. 2.

Dockendorff Gp., Chapman Sandstone, Presque Isle, Maine.

Planolites ichnosp.: Fig. Spec. NBMG 4011/6,7

Hofmann and Patel, 1989. Geol. Mag. 126, p. 141, fig. 2b.

Saint John Gp., Ratcliffe Brook Fm., Cambrian, Hanford Brook, New Brunswick.

Protovirgularia dichotoma M'Coy: Fig. Spec. NBMG 9336-9340; 9342; 9347; 9348; 9351; 9352; Cited Spec. NBMG 9334; 9335; 9341; 9343; 9344-9346; 9349; 9350; 9353

Han and Pickerill, 1994b. Ichnos 3, p. 204, figs. 2 to 5.

Tobique Gp., Wapske Fm., Devonian, Riley Brook-Nictau, New Brunswick.

Psammichnites gigas (Torell): Fig. Spec. NBMG 4011/1-5; 4012

Hofmann and Patel, 1989. Geol. Mag. 126, p. 145, figs. 3a-c, 4a-e, 5.

Saint John Gp., Ratcliffe Brook Fm., Cambrian, Hanford Brook, New Brunswick.

Psammichnites ichnosp.: Fig. or Cited Spec.? NBMG 4565 Matthew, 1891. Trans. Roy. Soc. Can. 8 (4), p. 157.

Cambrian, Tabors Bridge, Hammond River, New Brunswick. Remarks: uncertain if this is Matthew's figured or cited specimen.

Rusophycus ichnosp.: Fig. Spec. NBMG 9946

Pickerill, 1995. Atlan. Geol. 31, p. 104, fig. 2.

Lotbinière Fm., Ordovician, Montmorency Falls, Quebec.

Subphyllochorda? ichnosp.: Fig. Spec. NBMG 4010/1,2

Hofmann and Patel, 1989. Geol. Mag. 126, p. 147, fig. 2d,e.

Saint John Gp., Ratcliffe Brook Fm., Cambrian, Hanford Brook, New Brunswick.

Taenidium barretti (Bradshaw): Fig. Spec. NBMG 9074; 9216; 9217

Keighley and Pickerill, 1994. Palaeontol. 37, p. 327, pl. 1, fig. 6a,b,c.

Pomquet Fm., Carboniferous, Grand Étang, Nova Scotia.

Taphrhelminthoida cf. T. circularis Crimes et al.: Fig. Spec. NBMG 4015

Hofmann and Patel, 1989. Geol. Mag. 126, p. 155, fig. $4 \mathrm{~g}$. Saint John Gp., Ratcliffe Brook Fm., Cambrian, Hanford Brook, New Brunswick.
Taphrhelminthoida dailyi Hofmann and Patel: Holotype NBMG 4013/1; Paratype NBMG 4013/2; Fig. Spec. NBMG 4014 Hofmann and Patel, 1989. Geol. Mag. 126,' p. 148, figs. 4f, 6a-f, 7.

Saint John Gp., Ratcliffe Brook Fm., Cambrian, Hanford Brook, New Brunswick.

\section{Problematica/Pseudofossils}

"Eozoon canadense " Dawson: Ref. Spec.? NBMG 8576; 8577

Matthew, 1890b. Nat. Hist. Soc. N.B. Bull., No. 9, p. 36. Precambrian, Saint John, New Brunswick.

Remarks: these are possibly the "Eozoon" specimens referred to by Matthew.

"Lepidostrobus": Fig. Spec. NBMG 8428

Matthew, 1907. Trans. Roy. Soc. Can. 1 (4), p. 185, fig. 1 Fyffe and Miller, 1992. Atlan. Geol. 28, p. 216, fig. 5.

Silurian, Flume Ridge Fm./Digdeguash Fm., Cox's Brook, New Brunswick.

Remarks: not a plant fossil, but a metamorphic feature.

"Orthoceratite": Ref. Spec.? NBMG 8620

Richardson, 1871. Geol. Surv. Can., 1870-71, p. 295.

Silurian?, Mistassini, Quebec.

Remarks: may be specimen or from group of specimens mentioned by Richardson (1871) and possibly the specimen noted by Matthew (1891).

Torellella laevigata (Holm): Fig. Spec. NBMG 10035 Landing, 1996. Can. J. Earth Sci. 33, p. 1189, fig. 5g.

Fosters Point Fm.?, Cambrian, Cradle Brook, New Brunswick.

\section{Chordata}

“Crossopterygian": Fig. Spec. NBMG 4607

Greiner, 1977. J. Paleont. 51, p. 50 pl. 1, fig. 2.

Albert Fm., Mississippian, Irishtown, New Brunswick.

Remarks: transfer of specimens to NBM cited in Miller (1989).

Latvius porosus Greiner: Holotype NBMG 4605; Paratype NBMG 4603 a,b; 4604; Fig. Spec. NBMG 4606

Greiner, 1977. J. Paleont. 51, p. 44, pl. 1, figs. 1,3 to 7 , text figs. 2 to 8.

Albert Fm., Mississippian, Irishtown, New Brunswick.

Remarks: transfer of specimens to NBM cited in Miller (1989).

cf. Megaptera novaeangliae (Borowski): Cited Spec. NBMG 4586/1-11

Miller, 1990b. Atlan. Geol. 26, p. 102.

Quaternary, Grande Anse, New Brunswick.

Odobenus rosmarus Linnaeus: Fig. Spec. NBMG 4559; 4584; 4585; 4587

Miller, 1990b. Atlan. Geol. 26, p. 98, fig. 2a,b,c,d. 
Quaternary, Bay of Fundy; Portage Island; St. Paul Village; Beresford, New Brunswick.

Odobenus rosmarus Linnaeus: Cited Spec. NBMG 4583; 4588-4593

Miller, 1990b. Atlan. Geol. 26, p. 103.

Quaternary, Granville Ferry, New Brunswick; Pictou Island, Nova Scotia; Gulf of St. Lawrence and Georges Bank.

Odobenus rosmarus Linnaeus: Cited Spec. NBMG 8621; 8722; $9105 ; 10026 ; 10029 ; 10045$

Miller, 1997a. Géograph. phys. et Quatern. 51, p. 108.

Quaternary, Bay of Fundy, New Brunswick.

\section{Megaplants}

Annularia latifolia minor Dawson: Holotype NBMG 3416 Matthew, 1906. Trans. Roy. Soc. Can. 12 (4), p. 126, pl. VII, fig. 4.

Cumberland Gp., Lancaster Fm., Pennsylvanian, Saint John, New Brunswick.

Cardiocarpon cornutum Dawson: Fig. Spec. NBMG 7123 Stopes, 1914. Geol. Surv. Can., Mem. 41, p. 89, pl. XXIII, fig. 62.

Cumberland Gp., Lancaster Fm., Pennsylvanian, Saint John, New Brunswick.

Dadoxylon ouangondianum Dawson: Fig. Spec. NBMG 8623 Matthew, 1910. Trans. Roy. Soc. Can. 3 (4), p. 77, pl. 1. Cumberland Gp., Lancaster Fm., Pennsylvanian, Saint John, New Brunswick.

Remarks: loaned by Matthew to J.W. Dawson, listed by Matthew as a cotype, may be part of syntype series examined by Dawson (1861, p. 165).

Dicranophyllum glabrum Dawson: Fig. Spec. NBMG 2130 Stopes, 1914. Geol. Surv. Can., Mem. 41, p. 79, pl. XVIII, fig. 47.

Cumberland Gp., Lancaster Fm., Pennsylvanian, Saint John, New Brunswick.

Pecopteris miltoni Artis: Fig. Spec. NBMG 7311

Stopes, 1914. Geol. Surv. Can., Mem. 41, p. 41, pl. VII, fig. 15 , text figs. 5,6 .

Cumberland Gp., Lancaster Fm., Pennsylvanian, Saint John, New Brunswick.

Rhizomorphia lichenoides Matthew: Holotype NBMG 8182 Matthew, 1907. Trans. Roy. Soc. Can. 12 (4), p. 186, fig. 1, pl. 1.

Lundblad, 1954. Svensk bot. Tidskr. 48 (2), p. 406.

Oostendorp, 1987. Bryophytorum bibliotheca. Band 34, p. 86, pl. XIIX, fig. 2.

Miller, 1997b. The Bryologist 100, p. 89, figs. 1, 2.

Cumberland Gp., Lancaster Fm., Pennsylvanian, Saint John, New Brunswick.

Remarks: assigned to the genus Thallites by Lundblad (1954).

\section{ACKNOWLEDGEMENTS}

The support of palaeontologists who have deposited reference material at the NBM is greatly appreciated. Special thanks to Dr. R. Pickerill, his students and colleagues, and the Department of Geology at UNB. Their assistance in recovering G.F. Matthew specimens from Princeton and their use of the NBM as a type repository has brought new life to a venerable collection. Thanks are also due to Janet Nice for assistance in compiling the list of fossils.

Chalmers, R. 1890. Report on the Surface Geology of Southern New Brunswick, Annual Report Part N, IV. Geology Survey of Canada, pp. 63-68.

Dawson, J.W. 1861. On the pre-carboniferous flora of New Brunswick, Maine, and eastern Canada. Canadian Naturalist and Geologist, 6, pp. 161-172.

-...- 1893. Being notes on the Pleistocene Geology of Canada, with special reference to the life of the period and its climatal conditions. Canadian Ice Age, pp. 212-269.

Donovan, S.K. and Pickerill, R.K. 1995. A camerate crinoid from the Upper Silurian (Ludlow) Moydart Formation of Nova Scotia, Canada. Atlantic Geology, 31, pp. 81-86.

Fillion, D. and Pickerill, R.K. 1990. Ichnology of the Upper Cambrian? to Lower Ordovician Bell Island and Wabana groups of eastern Newfoundland, Canada. Palaeontographica Canadiana, 7, $119 \mathrm{p}$.

FyFFe, L.R. and Miller, R.F. 1992. A note on reported plant fossils from the Flume Ridge area of southwestern New Brunswick. Atlantic Geology, 28, pp. 215-220.

Greiner, H. 1972. Arthropod Trace Fossils in the Lower Devonian Jacquet River Formation of New Brunswick. Canadian Journal of Earth Sciences, 9, pp. 1772-1777.

-.-- 1977. Crossopterygian Fauna from the Albert Formation, New Brunswick Canada, and its Stratigraphic-Paleoecologic Significance. Journal of Paleontology, 51, pp. 44-56.

Han, Y. and Pickerill, R.K. 1994a. Phycodes templus isp. nov. from the Lower Devonian of northwestern New Brunswick, eastern Canada. Atlantic Geology, 30, pp. 37-48.

---- 1994b. Taxonomic reassessment of Protovirgularia M'Coy 1850 with new examples from the Paleozoic of New Brunswick, eastern Canada. Ichnos, 3, pp. 203-212.

-..- 1995. Taxonomic review of the ichnogenus Helminthopsis Heer 1877 with a statistical analysis of selected ichnospecies. Ichnos, 4, pp. 83-118.

Hofmann, H.J. and Patel, I.M. 1989. Trace fossils from the type "Etcheminian Series" (Lower Cambrian Ratcilffe Brook Formation), Saint John area, New Brunwick, Canada. Geological Magazine, 126, pp. 139-157.

Keighley, D.G. and PickerilL, R.K. 1994. The ichnogenus Beaconites and its distinction from Ancorichnus and Taenidium. Palaeontology, 37, pp. 305-337.

LANDing, E. 1996. Reconstructing the Avalon continent: marginal-to-inner platform transition in the Cambrian of southern New Brunswick. Canadian Journal of Earth Sciences, 33, pp. 1185-1192.

LANDING, E. and Miller, R.F. 1988. Bibliography of George Frederic Matthew. In Trace fossils, small shelly fossils and the Precambrian-Cambrian boundary. Edited by E. Landing, G.M. Narbonne and P. Myrow. New York State Museum Bulletin 463, pp. 77-80.

LUNDBLAD, B. 1954. Contributions to the geological history of the Hepaticae: Fossil Marchantiales from the Rhaetic-Liassic 
coal mines of Skromberga (Prov. of Scania), Sweden. Svensk botanisk Tidskrift, 48, pp. 381-417.

MatTHEw, G.F. 1890a. On Cambrian organisms in Acadia. Transactions of the Royal Society of Canada, 7, pp. 135-162.

....- 1890b. Eozoon and other low organisms in Laurentian rocks at St. John. Bulletin of the Natural History Society of New Brunswick, 9, pp. $36-41,67$.

-.-. 1891. Illustrations of the fauna of the St. John Group. No. V (5). Transactions of the Royal Society of Canada, 8, pp. 123-166.

---- 1893. Illustrations of the fauna of the St. John Group. No. 7. Transactions of the Royal Society of Canada, 10, pp. 95109.

...-. 1899a. Studies on Cambrian faunas No. 3. - Upper Cambrian fauna of Mount Stephen, British Columbia. Transactions of the Royal Society of Canada, 5, pp. 39-66.

-...- 1899b. Studies on Cambrian faunas, No. 4. - Fragments of the Cambrian faunas of Newfoundland. Transactions of the Royal Society of Canada, 5, pp. 67-95.

-.-. 1906. A review of the flora of the Little River Group. Transactions of the Royal Society of Canada, 12, pp. 99-149.

...-- 1907. On some new species of Silurian and Devonian plants. Transactions of the Royal Society of Canada, 12, pp. 185-197.

.... 1910. Revision of the flora of the Little River. Transactions of the Royal Society of Canada, 3, pp. 67-113.

Miller, R.F. 1988a. Catalogue of Type Fossils in the New Brunswick Museum. Publications in Natural Science No. 7. The New Brunswick Museum, Saint John, 75 p.

---- 1988b. George Frederic Matthew (1837-1923). In Trace fossils, small shelly fossils and the Precambrian-Cambrian boundary. Edited by E. Landing, G.M. Narbonne and P. Myrow. New York State Museum Bulletin 463, pp. 4-7.

- 1989. Transfer of Devonian Type Specimens from New Brunswick. Journal of Paleontology, 63, p. 956.

---- 1990a. A note on Cyathospongia eozoica Matthew, a supposed sponge fossil from the Precambrian of New Brunswick. Canadian Journal of Earth Sciences, 27, pp. 473-475.

---- 1990b. New records of postglacial walrus and a review of Quaternary marine mammals in New Brunswick. Atlantic Geology, 26, pp. 97-107.

---- 1994. Palaeontologist William Diller Matthew: Early years in New Brunswick and the story of the giant trilobite. Geoscience Canada, 20, pp. 153-157.

---- 1995a. The holotype of Leaia silurica Matthew, 1910, Pennsylvanian, Lancaster Formation, New Brunswick. Atlantic Geology, 31, pp. 23-24.

---- 1995b. The status of Belinuropsis wigudensis Matthew, 1910, a Pennsylvanian merostome from New Brunswick, Canada. Atlantic Geology, 31, pp. 117-118.

---- 1996a. Location of trace fossils and problematica of George Frederic Matthew from Part W, Treatise on Invertebrate Paleontology. Journal of Paleontology, 70, pp. 169-171.

---- 1996b. Note on Pterygotus anglicus Agassiz (Eurypterida: Devonian) from the Campbellton Formation, New Brunswick. Atlantic Geology, 32, pp. 95-100.

....- 1997a. New records and AMS radiocarbon dates on Quaternary walrus (Odobenus rosmarus) from New Brunswick. Géographie physique et Quaternaire, 51, pp. 107-111.

--- 1997b. Note on the holotype of Thallites lichenoides, a supposed Pennsylvanian bryophyte. The Bryologist, 100, pp. 89-91.

MilleR, R.F. and BuHaY, D.N. 1988. The Steinhammer Club; geology and the foundation for a natural history society in New Brunswick. Geoscience Canada, 15, pp. 221-226.
Miller, R.F. and McAlpine, D.F. 1991. A review of echinoderms from Pleistocene marine deposits near Saint John, New Brunswick. Atlantic Geology, 27, pp. 111-117.

Miller, R.F., Fitzgerald, W.D., and Buhay, D.N. 1987. Fossil Coleoptera from a postglacial site near Minesing Swamp, Ontario. Canadian Journal of Earth Sciences, 24, pp. 2099-2103.

NoRman, Y.J.-C. and PICKeRILl, R.K. 1996. Lobichnus varabilis Kemper 1968 from the Devonian of Maine, northeastern U.S.A. Ichnos, 4, pp. 233-237.

Oostendorp, C. 1987. The Bryophytes of the Palaeozoic and the Mesozoic. Bryophytorum bibliotheca. Band 34, 112 p.

Pickerill, R.K. 1989. Compaginatichnus: A new Ichogenus from Ordovician Flysch of eastern Canada. Journal of Paleontology, 63, pp. 913-919.

-..-- 1990a. Repository of Trentonia shegiriana Pickerill and Forbes, 1978 (Annelida, Polychaeta). Journal of Paleontology, 64, p. 1041 .

-.-- 1990b. Nonmarine Paleodictyon from the Carboniferous Albert Formation of southern New Brunswick. Atlantic Geology, 26, pp. 157-163.

..... 1991. The trace fossil Neoereites multiserialis Pickerill and Harland, 1988 from the Devonian Wapske Formation, northwest New Brunswick. Atlantic Geology, 27, pp. 119-126.

...-. 1995. Deep-water marine Rusophycus and Cruziana from the Ordovician Lotbinière Formation of Quebec. Atlantic Geology, 31, pp. 103-108.

Pickerill, R.K. and Forbes, W.H. 1978. A trace fossil preserving its producer (Trentonia shegiriana) from Trenton Limestone of the Quebec City area. Canadian Journal of Earth Sciences, 15, pp. 659-664.

Pickerill, R.K., Donovan, S.K., Dixon, H.L., and Doyle, E.N. 1992. Bichordites monastiriensis from the Pleistocene of southeast Jamaica. Ichnos, 2, pp. 21-35.

Pickerill, R.K., Donovan, S.K., Doyle, E.N., and Dixon, H.L. 1993a. Ichnology of the Palaeogene Richmond Formation of eastern Jamaica-the final chapter? Atlantic Geology, 29, pp. 61-67.

Pickerill, R.K., Donovan, S.K., and Dixon, H.L. 1993b. The trace fossil Dactyloidites ottoi (Geinitz, 1849) from the Neogene August Town Formation of south-central Jamaica. Journal of Paleontology, 67, pp. 1073-1074.

Pickerill, R.K., Norman, Y., and Han, Y. 1995. New occurrence of Phycodes templus Han and Pickerill, 1994 with a taxonomic reassessment of Yangziichnus yichangensis Yang, 1984. Atlantic Geology, 31, pp. 1-5.

Richardson, J. 1871. Report on the Country North of Lake St. John. Geological Survey of Canada 1870-71, pp. 293-295.

Stopes, M.C. 1914. The "Fern Ledges" Carboniferous Flora of St. John, New Brunswick. Geological Survey of Canada, Memoir 41, $167 \mathrm{p}$.

Thomas, M.L.H., Grant, D.R., and DeGrace, M. 1973. A Late Pleistocene marine shell deposit at Shippegan, New Brunswick. Canadian Journal of Earth Sciences, 10, pp. 1331-1332.

Yochelson, E. 1981. A survey of Salterella (Phylum Agmata). United States Geological Survey, Open File Report 81-743, pp. 244-248. 